\title{
Men and abstract entities: individual responsibility and collective guilt in international criminal law
}

\author{
G E R R Y S I M P S O N *
}

Trials that reach the hearts and minds of Iraqis reinforce other important social and political messages. By establishing individual rather than collective responsibility for these crimes, they will place blame where it belongs: on the shoulders of Hussein and his cabal, and not on the Sunnis collectively or any particular village or clan.

... the latest and most formidable form of...dominion: bureaucracy or the rule of an intricate system of bureaus in which no men, neither one nor the best, neither the few nor the many, can be held responsible ... ${ }^{2}$

The true culprits are those who misled public opinion and take advantage of the people's ignorance to raise disquieting rumours and sound the alarm bell, inciting the country and, consequently, other countries into enmity. The real culprits are those who by interest or inclination, declaring constantly that war is inevitable, end by making it so, asserting that they are powerless to prevent it. The real culprits are those who sacrifice the general interest to their own personal interest. ${ }^{3}$

\section{Bosnia v Serbia}

On 26 February 2007, the International Court of Justice handed down its decision in the Bosnia $v$ Serbia (Genocide) case. ${ }^{4}$ The Court declared

* Professor of International Law, London School of Economics. Part of this essay was published previously as a chapter entitled 'Law's Subjects' in G. Simpson, Law, War and Crime: War Crimes Trials and the Reinvention of International Law (Polity, Cambridge 2007).

${ }^{1}$ E. Ward and M. Hieman, 'Iraqi run tribunal is major progress towards rule of law system' Christian Science Monitor, 19 July 2005: www.csmonitor.com/2005/0719/p09s02-coop. html, accessed 12 June 2008.

${ }^{2}$ H. Arendt, On Violence (Harcourt, Brace and World, New York 1970), p. 38.

${ }^{3}$ Baron d' Estournelles de Constant, Chairman, International Commission to Inquire into the Causes and Conduct of the Balkan Wars, 'Opening Statement' (1914).

${ }^{4}$ Bosnia and Herzegovina $v$ Serbia and Montenegro, Application of the Convention on the Prevention and Punishment of Genocide ('Genocide Judgment') Merits, Judgment (26 February 2007). From now on, I will use 'Bosnia' and 'Serbia' as shorthand for the two states involved (now three, since Montenegro's declaration of independence). 
that there had been a genocide in Bosnia but evidence for that genocide existed only in relation to one place: Srebrenica. ${ }^{5}$ Other attacks on civilian populations (in Sarajevo, in Goradze) were 'ethnic cleansing' (to use the political term) and, in all probability, crimes against humanity (to use the legal term) but they did not rise (or sink) to the level of genocide (in the technical, legal sense). In the case of Srebrenica, there had been a genocide but the Serbian state was not directly responsible for this genocide. ${ }^{6}$ Instead, Serbia had violated the Genocide Convention by failing to prevent this genocide (it had failed to exercise its influence over the likes of Karadzic and Mladic) and by failing to facilitate the punishment of those responsible for it (Serbia has not, despite repeated requests, surrendered General Mladic to the ICTY). ${ }^{\text {? }}$

The substantive part of the judgment begins on what must seem, from the perspective of interested laymen, an unusual note. The Court asks whether the Genocide Convention prohibits genocide carried out by states. ${ }^{8}$ While the majority in the Court agrees that it does, a significant minority takes the view that the Genocide Convention is not, to any significant extent, directed at the activities of states at all. For this latter group of judges, the Convention outlaws genocide when carried out by individuals; it is personal intent that is decisive for the purposes of assessing the nature of a particular offence (i.e. was there intent, on the part of an individual perpetrator, 'to destroy in whole or in part a particular group'?). In the end, a majority of judges accepted that the Genocide Convention had imposed obligations on states but they held that these were of a delictual nature. No judge envisaged state criminal responsibility for genocide.

What I want to explore in this chapter is the relationship between individual responsibility and state responsibility (and, in particular, state criminal responsibility) under international law. It is clear that this relationship is one of the keys to understanding the Bosnia $v$ Serbia case but it is also central to the way in which international criminal law itself plays out. For example, the Court, while assessing the responsibility of Serbia as a state, relies, to a great extent, on the findings of the International Criminal Tribunal for the former Yugoslavia in cases implicating individual responsibility (in particular, the Krstic case). ${ }^{9}$

${ }^{5}$ Genocide Judgment (n. 4) para. 297. ${ }^{6}$ Genocide Judgment (n. 4) para. 415.

7 Genocide Judgment (n. 4) para. 438. ${ }^{8}$ Genocide Judgment (n. 4) para. 166.

9 One topic I do not touch on to any great extent in this chapter concerns the distinction between collective groups with legal personality and those lacking it. The international system is founded on a demarcation between states and collective groups lacking 
This cross-pollination is somewhat typical of an international legal order in which state responsibility and individual culpability are symbiotic. Indeed, a number of those judges who were reluctant to read the Convention as imposing direct responsibility nonetheless accepted that states would incur responsibility where acts of individuals could be attributable to the state.

The Court, perpetually juggling the demands of statism with the imperatives of individual culpability, was concerned also to show that any finding of complicity to commit genocide depended on a prior finding that Serbia (or one of its organs) had acted 'knowingly' in aiding the Bosnian Serbs at Srebrenica. ${ }^{10}$ Again, this application of concepts of individual responsibility to state behaviour will appear odd to lay observers but entirely unremarkable to those familiar with international law's recurring patterns.

Ultimately, the relationship between individual and collective accountability rests on a dilemma facing those who seek to perform international criminal justice. This dilemma, in turn, reflects our intuition that mass criminality in war or peace is both collective and individual in nature. And this combination is present whether we consider the position of the perpetrator or victim. The perpetrator is both individually culpable (perhaps 'evil') and yet also embedded in a social structure or organizational matrix that, to some extent, 'determined' his crimes. The Jelisic court imagined a lone genocidal maniac ${ }^{11}$ but there is no record, in law or history, of such a person existing. Equally, the victims are individual human beings. Each death or injury is a personal disaster for the victim and the victim's family. But, in the case of genocide, the victim's status as a victim of genocide depends on her membership of a social group. No longer merely an individual victim, she acquires her special status because of the fact that she is part of a 'national, ethnic, religious or racial group'.

This chapter emphasizes one particular aspect of collective responsibility; namely state responsibility. However, international criminal law's collective 'face' encompasses more than simply states. And, as I discuss

statehood. This issue arose in Serbia's Application for Revision of the 1996 Judgment, wherein Serbia claimed that, in 1993, when proceedings were instituted by Bosnia, it lacked the legal personality that would permit it to be brought before the court. The Court rejected this argument in 2003 on res judicata grounds (there were five dissenting arguments).

${ }^{10}$ Genocide Judgment (n. 4) para. 421.

${ }_{11}$ Prosecutor v Jelisic, IT-95-10-A, Judgment, Appeals Chamber (5 July 2001). 
later, collective identities at a sub-state level (criminal enterprises, state organs) provide a linking point between the abstractions of state responsibility and the particularities of individual liability. It is important to understand, too, that system criminality (in the version articulated in this book) applies to both states and state (and non-state) organs. Culpability extends beyond the individual, and implicates (and is influenced by) the cultural, political and bureaucratic groupings of which the individual is, necessarily, a part. Before exploring more fully this relationship between group and personal victimhood and, more especially, collective and individual responsibility, let me begin this chapter by presenting an orthodox account of international criminal law's roots in a conception of individual responsibility.

\section{Men not abstract entities}

War crimes trials are understood and imbibed as dramas of individual human reckoning. The indelible imagery of the trial is that of the defendant facing up to his responsibility; accountable for his crimes before the court and the eyes of the world. In Jerusalem, there was Adolf Eichmann behind his glass booth looking out at his ' 6 million accusers'. ${ }^{12}$ At Nuremberg, two rows of variously dazed, defiant, emotionally crippled, high-ranking Nazis slowly absorbed a picture of the gross misdeeds contained in the accusations. In The Hague, there was Slobodan Milosevic bullishly facing down his accusers, and in Baghdad, the personality of an apparently remorseless Saddam Hussein has come to dominate the process of legalized retribution. But if popular understandings of the war crimes field are dominated by notorious individuals, this simply reflects an inclination in the academic and professional world of international law to think of international criminal law as an expression of the growing role of the individual in international law generally. International criminal law, indeed, is often understood as the application of individual responsibility to international law. While most international legal norms subject states to certain behavioural constraints and hold states accountable for breaches of these constraints, international criminal law has been regarded as controversial and innovative precisely because it makes individuals liable for infractions of international law's most fundamental norms. At Nuremberg, the International Military Tribunal declared, in its final judgment, that the hideous crimes under investigation were committed

12 G. Hausner, Justice in Jerusalem (Harper \& Row, New York 1966), p. 392. 
not by abstract entities but by men. ${ }^{13}$ This apparently commonsensical idea has by now become central to international criminal lawyers' selfunderstandings. ${ }^{14}$

Putting the individual at the centre of the international law project has been a distinguishing motif in much commentary in the field, but it is linked, too, to some other effects of the law of war crimes on the wider discipline. To take the most obviously significant, punishing individuals through criminal sanction is important because it promises the renewal, perhaps completion, of international law; because it links international law explicitly to international human rights law and anticipates the future enforceability of these norms; and because it contributes further to the recession of sovereignty (in the latter case, international criminal law is recruited to wider processes of globalization). Let me take each of these in turn.

First, international criminal law represents at least one possible future for international law. ${ }^{15}$ International lawyers have long been assailed by anxieties arising out of the apparent unenforceability of international law. This is, of course, partly a problem built into the very structure of international society. In particular, in a world in which many are sovereign, there is no single site of ultimate sovereignty. Many international lawyers have accepted that the international system is an anarchical society ${ }^{16}$ in which states must work to achieve certain global ends while at the same time preserving their freedom. To the extent that compliance is secured, it is done so through reciprocal sanctions, ${ }^{17}$ through the establishment of coalitions of like-minded states, ${ }^{18}$ through the self-identifications of states ${ }^{19}$ or through the work of global networks of state and non-state actors. ${ }^{20}$ Often, though, what appears to be missing from even the rosiest

${ }^{13}$ Nuremberg IMT, 'Judgment and sentence' (1947) 41 AJIL 221.

${ }^{14}$ G. Robertson, Crimes Against Humanity: The Struggle for Global Justice (The New Press, New York 1999), p. 655.

${ }^{15}$ F. Mégret, 'Justice in times of violence' (2003) 14 EJIL 327; Robertson (n. 14).

${ }^{16}$ J.S. Watson, Theory and Reality in the International Protection of Human Rights (Transnational Publishers, Inc., Ardsley, NY 1999).

17 A. D'Amato, 'Is international law really 'law'?' (1984/85) Northwestern University Law Review 75; F. Kratochwil, 'Thrasymmachos revisited: on the relevance of norms and the study of international law for international relations' (1984) 37 Journal of International Affairs 343.

18 F. Teson, 'A Kantian theory of international law' (1992) 92(1) Columbia Law Review 53.

19 C. Reus-Smit, The Politics of International Law (Cambridge University Press, Cambridge 2004).

20 A. M. Slaughter, The New World Order 2004 (Princeton University Press, Princeton, NJ 2004), pp. 14-44. 
portrayals of international law's muscularity or relevance is the possibility of simple criminal repression or top-down enforcement. In the case of the Iraq war, the tragedy of international law for most international lawyers lay in the breach of the law by two of the Great Powers. ${ }^{21}$ The system of habitual compliance and institutional fidelity had been violated. The solution for one group of international lawyers was the re-invigoration of international society through confidence-building among estranged allies and institutional renewal. ${ }^{22}$ This, indeed, was the official response of the United Nations in its High-Level Panel Report, ${ }^{23}$ and in the SecretaryGeneral's In Larger Freedom document, where the accent is firmly on avoiding future transgressions by strengthening the UN system and by elaborating principles that would make decisions concerning the use of force more transparent. ${ }^{24}$

Among other lawyers, though, there was a sense that law could only function if there was some sort of ex post facto punishment meted out to those who violated the rules. ${ }^{25}$ The solution to the problem of the unlawfulness of the 2003 Iraq war lay not just in finding the states concerned responsible but in the punishment of individual violators. In other words, this comprehensive system of rules elaborated over centuries was capable of completion only when it could offer the possibility of some form of retribution towards those individuals who disregarded its most fundamental precepts. But who is to be punished?

The structure of international society makes it difficult to punish states. International law is largely auto-interpretive and states are beholden to no super-sovereign. As the ICTY said in Blaskic: 'under international law States could not be subject to sanctions akin to those provided for in national criminal justice systems. ${ }^{26}$ States make and enforce international law and they have shown a marked reluctance to devolve powers of punishment to international organizations. In any case, states may not be a suitable object of punishment. The project of completing international

${ }^{21}$ P. Sands, Lawless World (Penguin, Harmandsworth 2005).

${ }^{22}$ J. Brunnée and S. J. Toope, 'The use of force: international law after Iraq' (2004) 53 International and Comparative Law Quarterly 785-806.

${ }^{23}$ See Report of the Secretary-General's High Level Panel, A More Secure World: Our Shared Responsibility, available at www.un.org/secureworld, accessed 8 July 2008.

${ }^{24}$ See Report of the Secretary-General of the United Nations for Decision by Heads of State and Government in September 2005, available at www.un.org/largerfreedom, accessed 8 July 2008.

25 D. Bacher and B. Weston, Bush's Illegal War (30 May 2003) at www.counterpunch.org/ bacher05302003.html, accessed 12 July 2008.

${ }^{26}$ Prosecutorv Tihomir Blaskic, IT-95-14-T (3 March 2000). 
law, or making it more like domestic law, seemed to require, then, the punishment of individual violators. Bad men were to be incarcerated. This was the thrust of much commentary around the Iraq War. If the US and the UK really were guilty of breaching international law then, surely, the natural consequence of this was the indictment of the war leaders. This approach was reflected in the questions asked by journalists, in the anti-war banners carried by protesters ('The war is illegal, Bush and Blair are war criminals') and by the various efforts to have US and UK officials indicted before the international criminal court. Only individualized justice could ensure the relevance and meaningfulness of international law. Abstract entities were out, flesh and blood human beings were in.

The personalization of international law through international criminal law is linked to a second, broader trend: the emergence of human rights as a field. The move from thinking of international law in terms of 'abstract entities' to conceiving of it as a legal order about individual human beings begins at Nuremberg, and transforms the soul of international law. No longer exclusively about states (or, to a much lesser extent, organizations), it now becomes fixated on the rights and duties of individuals. This is so much so that there is an equation in the public mind of 'human rights' with 'international law'. At least since Nuremberg, states have been seen as potentially self-destructive, rapacious and violent. Initially, at least, the human rights system, while it attempted to place the security and integrity of individual human beings centre stage, still made respect for human rights a matter of state responsibility. The perceived early failure of human rights instruments can be traced to an erroneous assumption that states would hold each other responsible for any breaches of personal rights. This has happened only very rarely. Greece was taken to the European Court of Human Rights by Denmark, Sweden, Norway and the Netherlands, ${ }^{27}$ and the UK was sued by Ireland over the treatment of IRA detainees, ${ }^{28}$ but overall the record has been patchy. Even where mechanisms of individual petition were established, such as under the International Covenant for Civil and Political Rights, states found to be in breach of human rights obligations remained under only a weak obligation to remedy any abuses. And, of course, it was states themselves, despite the Nuremberg judgment, that continued to be the relevant 'entities' for the purposes of attributing responsibility,

27 Denmark, Norway, Sweden and the Netherlands $v$ Greece, The Greek Case, Application No. 3321/67, 3322/67, 3323/67 and 3344/67, Council of Europe, European Commission of Human Rights (5 November 1969).

${ }^{28}$ Ireland v The United Kingdom, ECtHR, Application No. 5310/71 (18 January 1978). 
even if it was individuals who were doing the torturing or killing. The International Law Commission had exercised itself with the question of state responsibility for almost half a century before its Articles on that topic were adopted by the General Assembly in $2001 .^{29}$ The move to individual responsibility, then, in international criminal law, modifies this tendency and has been hailed as a way of giving human rights law the bite it was thought to lack.

Third, international criminal law promises to further advance the demise of sovereignty. In this sense, the recent explosion of institutional innovation in criminal law is hitched to wider trends in the direction of globalization. As the state recedes in importance in the economic, cultural and political spheres, it seems appropriate that its centrality in international law should also disappear. ${ }^{30}$ Thus, the trials of Milosevic and Kambanda, and the decision in Pinochet, seem explicitly to deny states some of the privileges they once held in the international order. This is why in encomiums to globalization, the ICC is frequently invoked alongside the WTO, the loosening of state ownership and the deregulation of trade and capital. Sometimes, too, international criminal law is associated with the triumph of global individualism or some form of cosmopolitanism. The Statute of the International Criminal Court reveals the lineaments of a new global justice order. ${ }^{31}$ Daniele Archibugi makes this link explicit: 'For all their flaws, existing bodies [of international criminal law] are the embryos of more robust ones that will be needed to guarantee global legality ... a fully-fledged international criminal court needs to be set up'.

But it turns out that, despite the claims and promises made by its keenest proponents, international criminal law or the law of war crimes is not, and has not been at its origins, exclusively dedicated to this methodological individualism that lies at the heart of much international justice rhetoric, human rights law and cosmopolitan enthusiasm for international criminal law. Instead, what we find, and what I want to discuss in the remainder of this essay, is a perpetual movement between

${ }^{29}$ ILC Articles on State Responsibility (2001): http://lcil.law.cam.ac.uk/ILCSR/articles(e). doc, accessed 12 June 2008.

${ }^{30}$ M. Koskenniemi, 'The future of statehood', in G. Simpson, The Nature of International Law (Ashgate, Aldershot 2001); H. Koh, 'Transnational law', in G. Simpson, The Nature of International Law (Ashgate, Aldershot 2001).

31 D. Hirsh, Cosmopolitan Trials (Glasshouse Press, London 2003).

32 D. Archibugi and M. Koenig-Archibugi, Debating Cosmopolitics (Verso, London 2003), p. 268. 
the collective and the individual. ${ }^{33}$ This manifests itself in a number of different relationships. In section III, below, I discuss a series of institutional choices made throughout modern history between the criminalization of states (what I call, the Versailles Model) and the punishment of individuals (the Nuremberg Model). I conclude that these two models now coexist rather uncomfortably in the contemporary practice of international law with the paradigm instances in each case being the treatment of Iraq after 1991 (and, in particular, Security Council Resolution 687) and the establishment of the ad hoc and permanent Tribunals in The Hague and Arusha.

Next, in section IV, I turn to the way in which collective responsibility tends to be built into the doctrinal architecture of much of international criminal law even in its putatively individualistic mode. International criminal law, understood as the trial of individual violators by international courts, cannot escape into individualism entirely. It finds itself perpetually drawn back to group responsibility and communal guilt. In an analysis of the work of tribunals at Nuremberg and The Hague (and here I advert to the Rome Statute, too), I show how doctrines such as Joint Criminal Enterprise, organizational criminality and conspiracy betray international criminal law's roots in what George Fletcher has called a romantic view of history and personality, i.e. one in which the individual's behaviour is motivated by, and can only be understood in reference to, larger communities of nation, state or tribe. ${ }^{34}$ Finally, in section $\mathrm{V}$, I turn to broader questions around the structure of war crimes trials and the way in which that structure itself reflects our moral intuitions about responsibility for mass atrocity as well as our apparent allergy to collective punishment and our willing recourse to it. And I show, too, how the relationship between individual evil, structural deformity and the tragedy of being human is implicated in all this.

Ultimately, this chapter presents the field of international criminal law, or war, law and crime, as a perpetual bargain (played out in institutional history, in doctrinal innovation and in the structuring principles of

33 This resolves itself as (at least) four models of criminality. The first is the responsibility of individuals qua individuals. Here I refer to the trial of soldiers who commit extraordinary crimes of war without any authority from their superiors. Second, is the liability of officials who commit crimes on behalf of the state. Here the collective and the individual become mixed. The third model is organizational criminality of the sort seen at Nuremberg, and the fourth model is state crime (a fifth model might attribute some responsibility to the very structure of international society itself).

${ }^{34}$ G. Fletcher, 'The Storrs Lectures: liberals and romantics at war: the problem of collective guilt' (2000) 111 Yale Law Journal 1501-73. 
both international society and our moral intuitions) between individual blameworthiness and collective guilt.

\section{State crime and individual responsibility}

The modern institutional trajectory of international criminal law can be understood as a series of movements between collective guilt and individual responsibility. This history begins at Versailles with the peace imposed on Germany following the First World War, a model of peace repeated to some extent in criminalization efforts at the end of the twentieth century in Iraq, in Libya and in Serbia. ${ }^{35}$ The Versailles settlement represents, then, the first such de facto criminalization of pariah states in international legal history. Previous post-war rearrangements had contemplated forms of demilitarization or sanctions imposed on defeated states (e.g. the Congress of Vienna in 1815, the peace imposed on France at the end of the Franco-Prussian war of 1872) but none before had placed a state under such intense levels of scrutiny nor applied a regime as punitive as that found at Versailles. Versailles represents the moment when the modern international law of institutions begins, and with it the possibility of applying the machinery of institutional oversight to whole nations. Narrow definitions of criminal law (requiring criminal courts ${ }^{36}$ or incarceration (Blaskic)) need to be modified when we contemplate the way in which certain states are stigmatised and punished by international society. ${ }^{37}$ Prior to Versailles, and it is a view that persists to this day, violations of international law were understood as largely bilateral: one state's acts caused injury to a second or third state. Such breaches were dealt with at an inter-state level through a negotiated settlement of claims, or, occasionally, a form of arbitration or through the employment of counter-measures by the injured state. ${ }^{38}$ Civil or private law is the appropriate model for understanding international law in

35 D. Bederman, 'Collective security, demilitarization and "pariah states"' (2002) 13(1) EJIL 121.

${ }^{36}$ R. Higgins, Problems and Processes (Clarendon Press, Oxford 1995).

37 G. Simpson, Great Powers and Outlaw States: Unequal Sovereigns in the International Legal Order (Cambridge University Press, Cambridge 2004).

38 This was the case even in the laws of war. Violations of these laws was a matter of interstate responsibility. E.g. Art. 3 of Hague IV (1907) states: 'A belligerent party which violates the provisions ... shall, if the case demands, be liable to pay compensation.' This includes compensation for individuals. See also C. Greenwood, 'International humanitarian law', in F. Karlshoven (ed.), The Centennial of the First Peace Conference (Kluwer Law, The Hague 2000). 
this traditional mode. This legal order is composed of a matrix of bilateral relations with the civil suit being paradigmatic (represented by the inter-state dispute settlement mechanism at the International Court of Justice).

By the time of Versailles, though, the Great Powers had begun to see themselves as an incipient international community. Serious violations of that community's dominant mores were no longer thought to be a matter of merely dyadic concern but were understood or reconfigured into a breach of the rights of all states acting as an international society. At least one of the conditions for the existence of the criminal law was now satisfied - the self-consciousness (and self-righteousness) of a moral community (albeit one largely directed by the Great Powers). This selfrighteousness translated into a new belief that victory and defeat in war was not simply matter of luck or strategy but also implicated questions of collective virtue and criminality. ${ }^{39}$ This combination of institutional self-confidence, community self-awareness, and legalism produced the Versailles settlement and the criminalization of Germany. Germany was punished by the society of states, and the extent and intensity of its punishment was akin to that of the criminal sanctions found in many domestic legal orders. The Versailles model of state criminality was marked by a number of highly distinctive qualities.

First, the criminal state was adjudged to have breached one of the fundamental norms of the international legal order. It was never made absolutely clear what norm had been breached but there was general confidence among the statesmen of the time that the German state and its leadership were responsible for a war that the Canadian Prime Minister, Robert Borden, rather misleadingly, called a 'crime against humanity' ${ }^{40}$ Second, the contractual relationship usually found in armistice and peace agreements with accompanying amnesties ${ }^{41}$ (between two private parties, justi hostes) was transformed into a relationship between representatives of the legitimate political order and the outlaw state. ${ }^{42}$ International law underwent a shift from sovereign equality to centralized enforcement and from society to community. Third, the state in question (Germany in this case) was deprived of some of its basic

39 C. Schmitt, The Nomos of the Earth, in the International law of the Jus Publicum Europeaeum (Telos Press, New York, NY 2003); R. Pal, Crimes in International Relations (University of Calcutta Press, Calcutta 1955).

${ }^{40}$ G. J. Bass, Stay the Hand of Vengeance: The Politics of War Crimes Tribunals (Princeton University Press, Princeton, NJ and Oxford 2000), p. 65.

${ }^{41} \mathrm{Pal}$ (n. 39) 399. $\quad{ }^{42}$ Schmitt (n. 39) 262. 
sovereign prerogatives. In Germany's case, the state lost some of its territory, was forced to pay highly punitive damages (in the Entente Note of 10 January 1917, the Allies declared that Germany's liabilities were without limit because it had engaged in an aggressive war) and was obliged to undergo a process of demilitarization underwritten by the international community and overseen by, often ad hoc, international bureaucracies (e.g. the Inter-Allied Commissions of Control charged with ensuring that Germany disarmed). In addition, the criminal state in this case was placed under notice that any breach of the enhanced regime of oversight could result in a resumption of hostilities or an enforcement of treaties of guarantee. ${ }^{43}$

This Versailles model, of course, fell into serious disrepute shortly after it was imposed. Many contemporary critics blamed it for the breakdown in the European order less than two decades later. John Maynard Keynes famously predicted the dire consequences of criminalising Germany, the United States displayed a marked reluctance to support the more punitive aspects of the settlement, and, of course, the effects of the peace on the German population at large were felt by many people to have been fundamentally unjust. Some of the fault for the rise of the Nazis and the onset of war was laid at the door of the Versailles settlement. It is little wonder, then, that when the Second World War ended, the Allies appeared to renounce the idea of state criminality and resorted to a rejuvenated model of individual responsibility. Nuremberg was a riposte not only to conventional international law with its relentless focus on states' 'civil' liability but also to the state crime model pursued without much success at Versailles.

The orthodox account, then, of the war crimes trials at Nuremberg and Tokyo argues that they were fashioned with a view to cleansing Japan and Germany of collective guilt. The absence of the Emperor from the list of defendants at Tokyo, for example, can be viewed as a symptom of this effort, since he was viewed as a symbol of the nation rather than an individual capable of having committed a crime. At Potsdam on 26 July 1945, the Allies offered the following reassurance: 'We do not intend that the Japanese shall be enslaved as a race or destroyed as a nation'. At Nuremberg, too, there was a rhetorical tendency to shift responsibility from the German state to individual Germans and specifically Nazi institutions. The apparent exoneration of the Wehrmacht at Nuremburg and at the post-war Control Council Trials can be understood as part of this 
process of ridding Germany of the guilt of nations. ${ }^{44}$ The development of international criminal law after the Second World War was heavily influenced by the Cold War requirement that Japan and Germany be acquitted of any state crime. Alongside this, the failure to define and criminalize aggression during debates at the United Nations in the 1950s meant that the focus of war crimes prosecutions would return to crimes capable of being carried out by individuals (war crimes, crimes against humanity and genocide).

The above account does not quite accord with the historical record, though. In 1944, the 'Nuremberg solution' was still in some important quarters a minority position. Churchill and Stalin had favoured summary executions of large numbers of Germans who were to be deprived of the right of a trial, and plans were underway to occupy and emasculate Germany. The most developed of these proposals adopted an even more punitive version of the Versailles model. This was US Treasury Secretary, Henry Morgenthau's Memorandum of September 1944. Here was a classic Carthaginian Peace. ${ }^{45}$ Under the Morgenthau proposal, Germany was to be de-industrialized and returned to a largely agrarian state denuded of military capability. This pastoralization of a great European state was to be accompanied by a series of 'political' actions against high-ranking Nazis (they were to be shot under summary procedure). The Morgenthau Plan was defeated by an unlikely coalition of American legalists (notably, Secretary of State Stimson) who wanted war crimes trials and Soviet officials who were happy to see the Nazis disposed of after some sort of show trial. ${ }^{46}$ The British reluctantly joined with the group seeking trials, and Morgenthau was left isolated and disappointed. The defeat of the Morgenthau Plan is sometimes taken to represent the triumph of liberal legalism and individual responsibility over vengeful politics and collective guilt.

However, elements of Morgenthau's Plan survived alongside Nuremberg. Most notably, of course, the state of Germany was divided into four zones and then two political entities. It was, in effect, temporarily extinguished as a state (this was accompanied by the brutal treatment accorded to German POWs). ${ }^{47}$ But, alongside this, there was the designation of Germany (and Japan) in the United Nations Charter

${ }^{44}$ D. Boxham, Genocide on Trial: War Crimes Trials and the Formation of Holocaust History and Memory (Oxford University Press, Oxford 2001).

${ }_{45}$ M. Beschloss, The Conquerors (Simon \& Schuster, New York 2002); Bass (n. 40).

${ }^{46}$ Beschloss (n. 45).

47 J. Bacque, Other Losses (Stoddart Publishing Co. Ltd, Toronto 1999). 
as 'enemy states', against whom military action could be undertaken without reference to the UN's standard provisions restricting the use of force. ${ }^{48}$ In any case, at least as far as the US Zone was concerned, the Morgenthau Plan was supplanted by JCS Directive $1067^{49}$ and the Potsdam Protocol (1945). ${ }^{50}$ The Directive, which was recommended as practice for the other four controlling authorities, contemplated a highly intrusive programme of economic control, decentralisation of indigenous political power and complete military and 'industrial' disarmament (indeed, the directive cautions controlling authorities from taking any action that would enhance German economic power). The Potsdam Protocol (1945), meanwhile, set out the conditions for FourPower Occupation. These included action to permanently prevent 'the revival or reorganisation of German militarism' (Principle 3(a)) and the encouragement of primarily agricultural production (Principle 13). The Potsdam agreement, then, to a certain extent, undercut the apparent purpose of the Nuremberg Tribunal by setting out as its core principle the need to:

Convince the German people that they have suffered a total military defeat and that they cannot escape responsibility for what they have brought upon themselves, since their own ruthless warfare and the fanatical Nazi resistance have destroyed German economy and made chaos and suffering inevitable.

(Principle 3ii)

This was far removed from the IMT's move from abstract entities or collective responsibility to individual guilt. Here, the romantic idea of attributing agency to the nation had supplanted (or, at least, supplemented) the liberal project of punishing individualized and autonomous moral behaviour.

It is clear, then, that the origins of contemporary international criminal law in post-war Germany are found in both the 'stern [individualized] justice' (Moscow 1943) meted out at the IMT and the broader notions of collective responsibility applied at Potsdam. It is no surprise that the present period is one in which these two conceptions of

\footnotetext{
48 This provision has been recommended for removal in the World Summit Report (2005); see also F. Kirgis, International Law Aspects of the 2005 World Summit Outcome, available at www.asil.org/insights/2005/10/insights051004.html, accessed 8 July 2008.

49 Directive of the Commander-in-Chief of United States Forces of Occupation Regarding the Military Government of Germany (April 1945).

${ }^{50}$ Potsdam Protocol (2 August 1945).
} 
accountability - individual responsibility and state crime - have both come to occupy prominent positions in the international legal armoury. By the time of the revival of international criminal law in the 1990s at The Hague, individual responsibility was an important means by which the Great Powers could respond to mass atrocity and rogue states could be rehabilitated. In emphasizing the subjective roots of criminality and deviance, the turn to individual responsibility had the potential to cleanse the state of responsibility (and, at the same time, exonerate the state system). We need only think of the way the states drafting the statute for an international criminal court sometimes imagined their task. In order to proceed effectively, states parties negotiators had to envisage themselves as acting on behalf of states and the state system against rogue individuals apparently disconnected from these same states. So, the call was for 'international cooperation' and for states to exercise their duty to punish perpetrators (Preamble). The field of struggle was to be between states applying the techniques of criminal repression (jurisdiction, coordination, detection) and rogue individuals determined to disrupt that system by committing gross violations of the public order (often on behalf of rogue groups or outlaw states). In Security Council Resolution 1593, referring the Darfur human rights abuses to the International Criminal Court, the Council, in Operative Paragraph 2, called on Sudan to cooperate with and provide assistance to the Court in its investigations. International criminal law relies on the fiction of detachability. The state, whether it is Serbia or Sudan, is imagined as an entity distinct from its bad apples and rogue statesmen. For Carla Del Ponte, this was the message of the Milosevic Trial. The Serbian people were the innocent dupes of a powerful criminal mind. Indeed, the Serbs, too, had been wronged by Milosevic. At the beginning of her opening statement, the Prosecutor provides a perfect summation of the individualised version of international criminal law:
The accused in this case, as in all cases before the Tribunal, is charged as an individual. He is prosecuted on the basis of his individual criminal respon- sibility. No state or organisation is on trial here today. The indictments do not accuse an entire people of being collectively guilty of the crimes, even the crime of genocide. It may be tempting to generalise when dealing with the conduct of leaders at the highest level, but that is an error that must be avoided. Collective guilt forms no part of the Prosecution case. ${ }^{51}$

51 See Del Ponte's Words: 'An almost medieval savagery', The New York Times, 13 February 2002, available at http:/query.nytimes.com/gst/fullpage.html?res=9407E0D91F3CF930 A25751C0A9649C8B63, accessed 8 July 2008. 
She goes on to say however: 'I do, of course, intend to explore the degree to which the power and influence of the accused extended over others.' It is this 'exploration' that is the subject of the next section, in which I consider those doctrines of international criminal justice that seek to situate the individual accused within a criminal enterprise or community of responsible persons. Historically, as I have noted, the attention given to collective guilt has resolved itself as a focus on the societal liability found, for example, at Versailles and at Potsdam. This inclination has not disappeared, and indeed, seemed newly invigorated at precisely the point when the idea of individual justice through international criminal tribunals was itself undergoing a revival.

This re-invigoration happened largely in three domains. First, at the United Nations, the premier law reform body in the international system, the International Law Commission, elaborated a set of principles to which sought to distinguish ordinary wrongs committed by states with a group of breaches that appeared to be more fundamental than mere delicts. In other words, the ILC considered whether to import the distinction between tort and crime from domestic law into public international law. As one commentator asked: 'Can a state commit a crime?'52 In its 1996 Draft, the Commission defined a series of acts that would give rise to criminal liability on the part of states. ${ }^{53}$ These included genocide, aggression and serious environmental offences (Article 19). More importantly, the Commission developed rules outlining the consequences to be attached to such criminal acts. The most significant of these, found in Articles 43, 45 and 52 of the Draft Articles, contemplate placing criminal states within a special juridical category whereby any reparations or sanctions imposed on them would have seriously deleterious effects on the sovereignty, immunity and dignity of such states. ${ }^{54}$

These principles resembled, in some respects, the Versailles Model discussed earlier. States were to be subject to uniquely punitive quasipenal sanctions and, in a rather unfortunate nod to the Versailles Treaty, Article 52 declared that sanctions directed against criminal states (or restitution claimed from the criminal state) would not be subject to the normal limitations set out in Article 42 (typically, and for cases involving mere delictual liability, restitution was only permissible to the extent

\footnotetext{
52 A. Pellet, 'Can a state commit a crime? Definitely, yes!' (1999) 10 EJIL 425.

53 Draft Articles on State Responsibility, Official Records of the General Assembly, Fifty-First Session, Suppl. No. 10, A/51/10 and Corr, 1 International Law Commission (1996) Art 19.

${ }^{54}$ Simpson (n.37).
} 
that it '... would not seriously jeopardize the political independence or economic stability of the State which has committed the internationally wrongful act, whereas the injured State would not be similarly affected if it did not obtain restitution in kind'). Criminal states under the system envisaged by the ILC would be in a similar situation to post-Versailles Germany. As was the case with Germany, then, sanctions would be applied to contemporary criminal states regardless of the consequences on the internal politico-economic order. A critical attribute of state sovereignty, the dignity of states, would be denied the outlaw state in the name of enforcing higher order international law.

Five years prior to the drafting of the 1996 Articles, the Security Council passed Resolution $687 .{ }^{55}$ From at least that point onwards, Iraq became a criminal state and its people subject to collective punishment. The second domain in which the idea of collective responsibility re-emerged was that of the Security Council. The Council deprived Iraq of part of its territory and prohibited it from acquiring certain types of weaponry. The people of Iraq, meanwhile, suffered seriously as a result of sanctions. The UN Population Fund released a report in 2003, stating that the number of women dying in childbirth had tripled between 1989 and 2002 and the respected British medical journal, The Lancet, published research in 1995 suggesting that 567,000 Iraqi children had died as a result of sanctions. ${ }^{56}$ In the succeeding decade, the outlawry of whole states became a favoured technique of international administration in Serbia, in Afghanistan and in relation to Iraq. These states were confined within a system of surveillance and oversight, deprived of the traditional privileges of sovereignty and reduced to a state of impoverishment. This was the state system's equivalent of 'incarceration' (Blaskic), and, despite the protestations of the Great Powers and the international community, the result was a form of old-fashioned collective punishment directed at a population at large.

Alongside all this, and this representing the third sphere in which the idea of state crime has emerged, the Great Powers themselves began to deploy the image of the criminal state in their rhetoric (Prime Minister Blair's 'irresponsible states' and President Bush's 'enemies of civilization', each recalling Roosevelt's description of the Nazi State as an

55 Resolution 687, adopted by the Security Council on its 2981st meeting (3 April 1991).

56 A. F. Presse, 'Death rate of Iraq mothers triples, UN survey finds' (4 November 2003): according to the study the number rose from 117 cases of maternal death per 100,000 live births in 1989 to 310 in 2002; S. Zaidi and M. C. Smith Fawzi, 'Health of Baghdadi children', The Lancet, 2 December 1995, p. 356. 
'international outlaw' ${ }^{57}$ and 'not a military enemy but an enemy of all law', ${ }^{58}$ in the work of government bureaucracies (the State Department's 'states of concern'), in legislation (the US Anti-Terrorism and Effective Death-Penalty Act 1996), a statute suspending the operation of sovereign immunity in cases where a designated terrorist state is sued in the United States by (American) victims of acts of terrorism, placed a group of states on a terrorist list), ${ }^{59}$ and in legal memoranda seeking to justify the illegal detention of enemy combatants on Guantánamo Bay (Gonzales Memorandum). These developments were reflected in turn by scholarship that sought to draw distinctions between civilized, democratic or decent states, and indecent outlaws, ${ }^{60}$ and in the turn to reparations in the UN's Human Rights system. ${ }^{61}$

The 1990s, then, was a decade in which the idea of individual responsibility certainly underwent an astonishing revival (the ICTY, ICTR and ICC). ${ }^{62}$ But, at the same time, and less visibly and self-consciously, the system was also embracing, again, the Versailles Model of state criminalization. The institutional history of international criminal law is captured in the Commentary on the 1996 Draft Code on Crimes Against the Peace and Security of Mankind where the ILC notes: 'The state may thus remain responsible and be unable to exonerate itself from responsibility by invoking the prosecution or punishment of the individuals who committed the crime', ${ }^{63}$ and in Article 25(4) of the ICC Statute: 'No provision in this Statute relating to individual criminal responsibility shall affect the responsibility of States under international law. ${ }^{36}$ The apparent historical inevitability and moral appeal of individual criminal responsibility is undermined by the temptations of collective responsibility. It may be that

57 R. Woetzel, The Nuremberg Trials in International Law (Stevens \& Son, London 1960).

${ }^{58}$ G. Schwarzenberger, Totalitarian Lawlessness and International Law (Jonathan Cape, London 1943), p. 85.

${ }^{59}$ US Anti-Terrorism and Effective Death-Penalty Act, section 221.

${ }^{60}$ Teson (n. 18); J. Rawls, The Law of Peoples (Harvard University Press, Cambridge, MA 1999).

${ }^{61}$ E.g. the UN Commission on Human Rights adopted Basic Principles and Guidelines on the Right to a Remedy and Reparations for Victims of Gross Violations (UN Doc E/CN.4/ RES/2005/35).

${ }^{62}$ Even Security Council Resolutions began to name individual violators of international law. This began with Osama bin Laden but there are now many individuals named in similar resolutions: E.g. SC Resolution 1521 (2003).

${ }^{63}$ Commentary to Art. 4 of the Draft Code of Crimes against the Peace and Security of Mankind (1996).

${ }^{64}$ Though it is not clear whether this provision refers only to state civil liability or whether 'responsibility' here can encompass forms of criminal responsibility. 
the tension between state crime and individual responsibility (exemplified by the fact that on 27 February 2006, in The Hague, two cases were being heard simultaneously: one, Prosecutor $v$ Milosevic, concerned the individual responsibility of the former Serb leader; the other, the aforementioned Bosnia $v$ Serbia, also about genocide but this time state responsibility for the crime of genocide) cannot be resolved because the structure of international society and the suppositions of our own belief systems rest upon that tension.

\section{The liabilit of men and things}

The coexistence of collective guilt and individual responsibility, identified in the discussion of institutional preferences in the field, is reflected at the level of doctrine even if, at first blush, international criminal law seems wedded to modes of liability that are highly individualistic. In some respects, it is a declaration of intent concerning personal liability - a turn from structure to agency - that marks off the international criminal law enterprise from the rest of the field of public international law. International criminal law's core instruments are concerned to advertise the centrality of individualized justice, just as the key commentaries are keen to enumerate its virtues. The statutes of the ICTY, ICTR and ICC follow the Nuremberg Principles by placing individual accountability centre-stage. The Charter of the IMT gives the Tribunal (in Article 6) jurisdiction over 'persons' who, acting as 'individuals', commit any of the listed crimes. The ICTY Statute states at Article 7(1): 'A person who planned, instigated, ordered, committed ... [a crime] ... shall be individually responsible for the crime.' Article 6 makes clear that this jurisdiction is to be found over 'natural persons' not abstract entities. The Rome Statute, too, refers consistently to natural persons and individual responsibility (Article 25). The law of war crimes, then, seems to mark a switch from the abstractions of the general field of public international law to the flesh and blood corporeality of human culpability. As Antonio Cassese puts it, the central idea behind individualized liability is that a defendant ought not to be punished for acts perpetrated by other individuals. Collective responsibility, as he puts it, is 'no longer acceptable'. ${ }^{65}$ These doctrinal efforts promise simplicity (it is no longer necessary to explain the reasons why crimes are committed - 'motive', as the Court in Jelisic noted, is not 
relevant to questions of intent), parsimony (the question of guilt is pared down to an investigation of one person's mental state and capacity) and depoliticization (the central questions become narrowly psychological rather than expansively political). ${ }^{66}$

These doctrinal projects, like the institutional ones discussed above, are frequently undone by the fact that the very acts criminalized under international law are those least susceptible to individualized justice. International criminal law's core offences are crimes against humanity, serious violations of the laws of war (war crimes), genocide and aggression. This is reflected in the IMT Charter at Nuremberg, and in the crimes included under Article 5 of the ICC Statute. In each of these cases, the typical crimes are, what Jose Alvarez called 'crimes of state', i.e. crimes arising from organizational tendencies or collective choices. ${ }^{67}$

Indeed, the rhetorical attention international criminal lawyers devote to individual responsibility is ill-matched to the mood of the general public when it comes to questions of responsibility. An example of precisely this tension occurred in 2005, when the UK government announced that it would begin prosecuting British soldiers for alleged war crimes committed during the occupation of Iraq in 2003. There was almost universal condemnation of this decision in the UK media. Many commentators and letter-writers, while conceding that the soldiers were accused of very grave crimes, could not imagine an international criminal law that applied to one-off acts of murder or assault committed by the personnel of states engaged in largely lawful combat. The commanding officer of the regiment most closely involved stated that: 'From the moment that Mr Baha Mousa lost his life while in our custody, the regiment has made clear that this was an isolated, tragic incident that should never have happened and which I and every member bitterly regret. ${ }^{68}$ In the House of Lords, similar sentiments were expressed:

What is now hanging over him and other soldiers is that the case may be referred to the International Criminal Court. That court was not set up for that purpose. It was set up to deal with cases of genocide and with war criminals. That that gallant officer [Colonel Mendoca, the Commanding Office of the soldiers accused of killing Baha Mousa in custody] could be

${ }^{66}$ Prosecutor v Jelisic (n. 11) para. 49.

${ }^{67}$ J. Alvarez, 'Crimes of states/crimes of hate: lessons from Rwanda' (1999) 24 Yale Journal of International Law 365.

${ }^{68}$ N. Tweedie, 'Uproar over war crimes trials' Daily Telegraph 21 July 2005, available at www.telegraph.co.uk/news/main.jhtml?xml=/news/2005/07/21/narmy21.xml, accessed 12 June 2008. 
in the same dock as that in which Milosevic has appeared must be wrong in itself. ${ }^{69}$

These commentators equate the idea of war crimes with the practice of mass atrocity. The Nazi genocide, and its contemporary variants, loom over the field as ideal types. The critics of the Willams and Mendoca investigations are responding to a legitimate sense that war crimes law, in its broadest sense, is about with mass criminality. This is a well-founded intuition. International criminal law, it turns out, even in its individualistic mode, is very often deeply concerned with structure. At a very obvious level, the Rome Statute restates this in its Preamble, and elsewhere. The negotiators were at pains to emphasise that the Court would have jurisdiction over only 'the most serious crimes of concern to the international community'. How are such crimes to be understood? In the case of aggression and genocide there is an in-built presumption against the idea that an individual can commit either of these crimes acting independently of a state apparatus. Aggression is an inter-state crime, defined as such in countless international instruments, and capable of being committed only if a group of individuals captures the machinery of the state. The discomfort expressed by the Commission on the Authorship of War in $1919^{70}$ is reflected in the continuing lack of agreement found in the negotiations for an international criminal court.

Likewise, the classic genocides of the twentieth century have been carried out either by states or state-like entities. One of the distinguishing elements of genocide is its sheer scale (in Jelisic, the ICTY discusses the possibility of the "lone genocidal maniac' ${ }^{\text {'1 }}$ but this figure is really more hypothetical than real and even the Court sounds unconvinced about the monster it has created). The mass killing of national, ethnical, racial or religious groups requires a degree of planning and organization typically beyond the capacity of all but state or state-like instrumentalities. ${ }^{72}$

${ }^{69}$ Lord Hoyle, Column 1223 (14 July, 2005) Hansard, available at www.publications. parliament.uk/pa/ld199900/ldhansrd/pdvn/lds05/text/50714-05.htm, accessed 12 June 2008.

70 The Commission on the Responsibility of the Authors of the War and on Enforcement of Penalties.

71 Prosecutorv Jelisic (n. 11).

72 There is nothing in the Genocide Convention itself to exclude the possibility of individual action. The Convention, after all, in the case of murder, refers only to the requirement that the accused has killed members of the group with an intent to destroy it in whole or in part. There is no requirement in the Statute that the killings be in any way substantial. Courts, though, have tended to understand genocide in precisely this way, e.g. the court 
Crimes against humanity and, in particular, war crimes appear at first glance to be quite different. The acts associated with these crimes murder, torture, hostage-taking, improper use of a flag of truce - are capable of being committed by individuals acting in an individual capacity. These crimes appear, then, to represent international criminal law's true face: the face of individualized justice. However, even here, at the definitional level, there are qualifications and conditions that disclose again this coexistence of the collective and the individual.

The International Criminal Court Statute defines crimes against humanity as acts (including murder, extermination and rape) committed 'as part of a widespread or systematic attack directed against any civilian population'. ${ }^{73}$ An earlier draft had made 'widespread and systematic' conjunctive but even in their eventual formulation it is clear that a requirement of collective action is retained. A systematic or widespread attack, after all, is not something that can be readily undertaken by a single individual. The definition of war crimes comes attached with a similar qualifier. While war crimes are defined as grave breaches of the Geneva Conventions and other analogous offences, the ICC is to possess jurisdiction only over such crimes in particular when committed 'as part of a plan or policy or as part of a large-scale commission of such crimes' ${ }^{74}$ This suggests that the ICC would lack jurisdiction over the likes of Mendoca and Williams (regardless of the substance of the accusations). Critics of the UK government, then, are simply drawing on a tradition in international criminal law, reflected in the Rome Statute, which understands 'war crimes' and 'crimes against humanity' as references to organized mass atrocity perpetrated in the Balkans and in the Second World War rather than the aberrant behaviour of British soldiers in Iraq.

This tension between individual agency and collective responsibility has been a powerful influence on the development of international criminal law since its putative inception at Nuremberg. The Nuremberg Trial represents a particular paradox in this regard because at the very moment when individual responsibility (the accountability of, what Churchill called the 'gang' of Nazis) was introduced onto the international scene in the form of individual trials, the American delegation was working behind the scenes to formulate charges that would imply a form of

in Krstic noted that 'the destruction in part must be of a substantial nature so as to affect the entirety' (para. 10).

${ }^{73}$ Art. 7 ICC Statute. ${ }^{74}$ Art. 8 ICC Statute. 
collective guilt. These ideas formed the backbone to the IMT Charter. In Article 6, the crime of aggression included the offence of participating 'in a common plan or conspiracy' for the accomplishment of planning or prosecuting aggressive war, and the final provision of that Article charged that those who participated in the formulation or execution of the common plan or conspiracy to commit Charter crimes would be 'responsible for all acts performed by any persons in execution of such a plan'. The purposes of the trial thereby began to work against each other. On the one hand, in order to precipitate the rehabilitation of Germany as a state, the Allies were keen to extract the poisonous elements from German society by identifying the ways in which the Nazi state had been captured and utilized for evil ends. On the other hand, the American conspiracy plan was meant to strike at the heart of that same society, and the broader the conspiracy claim became, the less plausible was its core proposition: that the conspirators were guilty of a massive organised conspiracy but the German people was innocent of participation in it. The idea that the leading German war criminals could be prosecuted with 'joint participation in a broad criminal enterprise' also contradicted one of the central pillars of the idea of individual responsibility because high-ranking Nazis would be prosecuted for acts committed by other individuals: 'Under such a charge there are admissible in evidence the acts of any of the conspirators done in furtherance of the conspiracy, whether or not these acts were in themselves criminal. ${ }^{75}$ The central core of individual responsibility, the mental culpability of the accused, was slowly stripped away by the drafters of the Statute.

The turn to the collective gathered pace around the idea of criminal organizations, too. When Stettinius met Eden and Molotov in San Francisco in the middle of 1945, the Americans had already formulated their plan to criminalize whole strata of German society:

We proposed to put on trial the Nazi organizations themselves rather than the individuals and convict them all of criminal conspiracy to control the world... Once having provided the organisation to be guilty, each person who had joined the organisation voluntarily would ipso facto be guilty of a war crime. ${ }^{76}$

The mass criminality outlined and envisaged in these plans, and in the core ideas of conspiracy and criminal organization, departed from western standards of individual guilt and personal responsibility at

75 Stimson et al., 'Memorandum for the President' (22 January 1945).

${ }^{76}$ M. Marrus, The Nuremberg War Crimes Trials (St Martin's Press, Bedford 1997), p. 35. 
the very moment of international law's apparent and much-trumpeted transformation from a body of law exclusively concerned with state responsibility to one in which individual humans and not abstract entities would be judged by the ideals of the international legal order.

International criminal law is revealed at its origins as a composition of collective and individual notions of responsibility, and this carries over to the trials in The Hague, where there are engineered a number of successor doctrines to those elaborated in the 1940s. At the ICTY, for example, the Court has developed a doctrine of 'joint criminal enterprise' (a phrase not even found in the ICTY's Statute). ${ }^{77}$ The Court deployed this in convicting Dusko Tadić, where it conceded that many crimes committed in war, rather than being individual acts of wrong-doing: 'constitute a manifestation of the collective criminality. ${ }^{78}$ Joint Criminal Enterprise is attractive to war crimes courts because it is sensitive to the reality of organized crime during periods of armed struggle..$^{79}$ More controversially, however, the doctrine is used by courts to avoid the responsibility of determining who actually killed or tortured in specific cases. It is sufficient that the court is able to show that the accused was involved in the system of criminality and had some knowledge of its ultimate criminal purpose. It has not always been necessary for the accused to have shared in that criminal purpose. As Verena Haan argues, Joint Criminal Enterprise is useful in difficult cases 'where the accused had acted in the sphere of politics' ${ }^{80}$ But this means criminalising political behaviour and, as well as the corollary of this, the politicization of criminal law. ${ }^{81}$

The scale of crime contemplated by international criminal law means that there is often likely to be present some element of organizational or mass criminality. Prosecutors and judges, particularly those concerned to steer a course between an absurd and a historical individualism (the idea that one person commits genocide or carries out ethnic cleansing) and a reductive structural determinism (the idea that the state or culture or people are guilty of these crimes at some collective level), are left with two awkward tasks. They must be satisfied that there is proof of personal guilt

77 See also the contributions by H. van der Wilt, 'Joint criminal enterprise and functional perpetration', this volume, Chapter 7 and E. van Sliedregt, 'System criminality at the ICTY', this volume, Chapter 8.

78 Prosecutorv Tadić, Appeal Judgment, IT-94-1 (27 February 2001) para. 191.

79 M. Osiel, 'The banality of good' (2005) 105 Columbia Law Review 1751.

${ }^{80} \mathrm{~V}$. Haan, 'The development of the concept of joint criminal enterprise at the ICTY' (2005) 5 International Criminal Law Review 167-201.

${ }^{81}$ See Prosecutor v Milosevic, Rule 98 bis Decision, IT-02-54-T, Trial Chamber (16 June 2004) para. 288 et seq. 
without ignoring the broader context in which crimes take place and they must limit the contextual investigations in order to secure the innocence of the society from which the perpetrators emerged.

\section{Three Eichmanns}

Amis: 'What is it with Americans and the death penalty?'

He goes on 'Instead of talking about Karla Faye Tucker, they're all talking about Monica Lewinsky' [Saul remained silent]

Amis: 'Don't tell me you're not against it either'

Bellow: 'Well. Look at...Eichmann. What are you supposed to do with a son of a bitch like that?'

Amis: 'Christ, you're really Old Testament, aren't you?' And he [Bellow] shrugged, and gave a sideways nod. ${ }^{82}$

The discussion up to this point has been concerned with the institutional and doctrinal responses to a complex relationship between individual guilt and collective responsibility. But this conflict, perhaps, reflects deeper tensions in the structure of international society and in our ethical predispositions. This is a chapter about international law and society not a philosophical treatise so I only have a limited amount to say about the latter question but it clearly animates and underpins the narrower questions of institutional (section IV) and doctrinal (section V) choice. Who, or what, commits war crimes, crimes against humanity or crimes against peace? This is a question with ethical, legal and political answers. As I have argued, the Nuremberg and Tokyo war crimes trials represented an attempt to individualize responsibility for war. Of course, prior to Nuremberg, lawyers had developed rules on the proper conduct of warfare but only very few criminal prosecutions associated with this body of norms had, by then, taken place (e.g. in Leipzig after the Second World War (Llandovery Castle, Dover Castle)) and these were highly unsatisfactory. ${ }^{83}$ Indeed, it was doubtful whether the existing legal rules anticipated or permitted criminal prosecution at all. Arguably, then, as we have seen, Nuremberg introduced into international law, the conceit of individual responsibility for gross crimes. But it also, and even more contentiously, developed principles of organizational criminality. So, while the Tribunal convicted von Ribbentrop, Goring, Streicher, Keitel et al. of having committed individual offences against the law of nations, it also

82 M. Amis, Experience (Jonathan Cape, London 2000), p. 260.

${ }^{83}$ Woetzel (n. 57); Bass (n. 40). 
declared whole organizations, such as the SS and the SD, criminal. This declaration, in turn, created the possibility of 'fixing the criminality of its members' ${ }^{84}$ However, this hardly solved, what David Luban called, 'the central moral challenge of our time the problem of moral responsibility in a bureaucratic setting. ${ }^{85}$

In thinking about criminality at the level found in the Nazi era or, to a lesser extent, during the Vietnam War and in Serbia, one is faced with a problem of structure and agency. The structural analysis of criminality inevitably focuses on processes, social behaviour, institutions, hierarchies and so on (i.e. deviance through the eyes of Kafka and Edelman). There are variations on this theme of structural explanation in Arendt's 'rule by nobody ${ }^{86}$ in Marx's bureaucratic mind ${ }^{87}$ and in Raul Hilberg's contention that: 'The killing...was no atrocity in the conventional sense. It was infinitely more, and that "more" was the work of a farflung, sophisticated bureaucracy. ${ }^{\prime 88}$ In the light of this, war crimes trials at best can appear as partial justice, at worst a form of 'scapegoating'.

Structural analysis can yield important insights but it is not without its failings, particularly when translated into legal norms attributing structural responsibility. On one hand, collective responsibility might result in a situation where everyone is guilty and, therefore, no-one is. Daniel Ellsberg, quoted by Sanford Levinson, speaks of the tendency to see Vietnam as 'a tragedy without villains, war crimes without criminals, lies without liars, a process of immaculate deception' ${ }^{89}$ On the other hand, the result of collective responsibility might be the criminalization of conduct that lacks the components of crime as traditionally understood by the liberal mind (mens rea and actus reus).

In approaching this dilemma, George Fletcher identifies a liberal bias in international criminal law's emphasis on agency or individual responsibility. This bias, he argues, 'obscures a basic truth' about war crimes. These are 'deeds that by their very nature are committed by groups and typically against individuals and members of groups'. ${ }^{90}$ For Fletcher, the tension between collective and individual notions of guilt or responsibility can

${ }^{84}$ Judgment of the International Military Tribunal at Nuremberg, Vol. 22 (1948), p. 500.

85 D. Luban, 'The Legacies of Nuremberg' (1987) 54(4) Social Research 779-829.

${ }^{86}$ Arendt (n. 2) 38. ${ }^{87}$ Marx, Critique (quoted in Luban (n. 85) 68 et seq.)

${ }_{88}$ R. Hilberg, The Politics of Memory (Ivan Dee, Chicago 2002), p. 59.

89 S. Levinson, 'Responsibility for crimes of war' (1973) 2 Philosophy and Public Affairs 244-73.

${ }^{90}$ G. Fletcher, 'The Storrs Lectures: liberals and romantics at war: the problem of collective guilt' 111 Yale Law Journal 1501-73. 
be understood through a contrast between what he calls 'romantic' and 'liberal' views of war and guilt. The liberal conception of responsibility is, of course, familiar enough. Liberals focus on individuals as free agents capable of making political choices, consuming freely, and, crucially, of doing wrong as individuals abstracted from the social group to which they belong. Criminal concepts like 'intent' go to the heart of this liberal view of individual human agency. Yet, a less familiar, romantic ontology also pervades international criminal law. This emphasises the role of the collective will and the idea of the people as the 'folk' or as an independent actor capable of greatness and, of course, great evil.

International criminal lawyers might be less surprised than Fletcher to discover this romantic sensibility permeates their work. After all, international law is replete with assumptions about 'the collective will'. The creation of legal norms through customary practice, for example, involves an acceptance that there can be such a thing as 'state consent'. Group guilt, however, is an idea that has made international lawyers uneasy since Versailles and criminal lawyers anxious since the onset of modernity. Fletcher wants to rehabilitate this idea but he does so with understandable caution. The individual and his or her responsibility 'remain central'. The danger of collective guilt (its vivid historical and biblical connotations and its ill-suitedness to criminal procedure and the rule of law) is obvious. However, Fletcher believes collective guilt has a role to play in mitigating the punishment of those individuals whose acts are both individual and also collective. To put it bluntly, an Eichmann or Milosevic who commit mass atrocities in the context of a diverse and decent society in which there is a clear possibility of self-correction is more culpable than the real historical Eichmanns and Milosevics. The 'climate of moral degeneracy' produced by the 'collective' contributes to the crime.

International criminal law, however, seems to work in the opposite direction. The prosecution of Milosevic was a way of punishing Milosevic for his crimes and the crimes of the Serbian state. Instead of mitigation we have exacerbation..$^{92}$ Because there is a desire to see Serbia rehabilitated (in international society, individuals are disposable but states much less so) and to ward off the dangers of Serbian revanchism, the emphasis is on producing some sort of closure through trial. Thus the oscillations of subjective and collective guilt were likely, prior to the former President's death, to resolve themselves, at least formally, through the conviction of Milosevic. But the credibility of this conviction from the perspective

${ }^{91}$ Fletcher (n. 90) 1541. $\quad{ }^{92}$ Fletcher (n. 90) 1542. 
of international criminal justice would have depended largely on how well the prosecution and Court were able to uncover the criminality of the Serbian state. After all, mass murderers are known for their notorious reluctance to kill people. Eichmann was famously squeamish at the sight of blood, and Albert Speer found his visits to concentration camps impossibly confronting. Likewise, it is possible that Milosevic had no history of direct killing. The emphasis, then, was on Milosevic's indirect responsibility, with the prosecution case resting largely on Milosevic's command responsibility for illegal acts committed by subordinates and for his leadership role in a joint criminal enterprise dedicated to the commissions of genocide, crimes against humanity and war crimes against Kosovar Albanians, Bosnian Muslims and Croats. Paradoxically, then, the more effective the Court was in building a record of mass atrocity and securing a conviction, the more likely it was to, indirectly at least, indict the Serbian people.

Coming to this dilemma from the opposite direction, Sanford Levinson, in an article written during the Vietnam War, argued that the problem lies not with a lack of mitigation but rather the absence of any responsibility at all. ${ }^{93}$ The dilemmas identified by Levinson are largely those of Fletcher, though the problem is presented differently. How is individual culpability and responsibility to be secured in the context of bureaucratic enterprises? Levinson believes this can be accomplished through a teasing out of individual command responsibility in times of war. He begins by rejecting three other possibilities. The first is to engage in collective criminal punishment. This is deemed unsatisfactory because of over-inclusiveness. Innocent citizens would become criminally liable. A second possibility is to impose civil liability on the state. This fails because tort-based remedies cannot capture the moral opprobrium associated with war crimes. The third possibility is to do nothing. Levinson worries about this option on the grounds that there would be no opportunity to 'restore a moral harmony which is dislocated when justice is done. ${ }^{94}$

According to Levinson, then, the preferred model is to be derived from the existing jurisprudence at Nuremberg and in particular at the trials following Nuremberg. War criminality depends on finding and prosecuting discrete criminals. ${ }^{95}$ The guilt of military and civilian leaders will be determined by their level of involvement in policy-making and implementation, the power they possess over that policy and the opposition they express

${ }_{93}$ Levinson (n. 89). $\quad{ }^{94}$ Levinson (n. 89) 273. $\quad{ }^{95}$ Levinson (n. 89) 251. 
towards criminal policies. (e.g. High Command Case). Armed with principles derived from the substantive jurisprudence of the tribunals and the law of command responsibility, a reasonable effort can be made to secure individual responsibility. Of course, as Levinson knows, this will work best in judging a regime dedicated to the meticulous documentation of state policy and its enactment (e.g. Nazi Germany) and will work less well in relation to a system in which power is diffuse, commands are informal and constitutional authority is enigmatic (the US in Vietnam). In the latter case, Levinson seems to argue for some informal procedures along the lines of the Russell Tribunal and the recently convened 'comfort women' trial. These trials have demonstrated that the failure of official criminal law to punish may not be fatal to efforts at stigmatising those guilty of international crimes.

Perhaps this debate, and international criminal law itself, simply reflects a wider need in the culture to see war criminals as at the same time uniquely evil ('no-one but Milosevic could have led the Serbs to such moral depths'), culturally representative ('Milosevic simply anthropomorphises a system gone horribly wrong') and typically human ('what would I have done in Milosevic's shoes?'). In the trial of Adolf Eichmann, these debates came to a head. If the law, war and crime dilemma at Nuremberg involved applying law to the problem of exceptional, unprecedented criminality, then the Eichmann trial revealed another perhaps more disturbing symptom of modern industrial society: the figure of the unexceptional political mass murderer. At Nuremberg and Tokyo, there are traces of the idea of 'ordinary' criminality but, the trials were largely dedicated to proving the existence of a criminal enterprise dictated by a small, but powerful, elite within Germany's heavily militarized and ideologically deformed society. Eichmann, though, presented a problem. Was he exceptional? Banal? Human?

In the most famous picture of Adolf Eichmann, he sits, inside the courtroom, in a glass booth, staring impassively ahead. The evil of the Holocaust is heaped upon this Eichmann. This Eichmann was portrayed in his trial as a 'hater', ${ }^{96}$ a man of exceptional evil who claimed he had not killed sufficient numbers of Jews, who disobeyed only one order - the command from Himmler telling him to cease the murders - and who charged Jewish children a half fare for the rail journey to Treblinka. ${ }^{97}$

96 L. Poliakov, Harvest of Hate: The Nazi Program for the Destruction of the Jews in Europe (Random House Schocken, New York, NY 1988).

97 T. Lacquer, 'Four pfennige per track km' (2004) 26(1) LRB. 
This is the Eichmann who was, in fact, profoundly evil in some ordinary sense. He regretted not killing more Jews in Europe, he showed no remorse for the Holocaust and he often boasted about his important role in mass murder and deportation. In a variation on this, there are portraits of Eichmann in which he is neither banal nor ordinary but, instead, a bureaucratic genius. This is the Eichmann who had overseen the destruction of the European Jews from a relatively small office and with a relatively small staff. ${ }^{98}$ Eichmann has been described as a clown, but he was a clown who played the violin and had read The Critique of Pure Reason. ${ }^{99}$ He applied his intelligence to a life shaped by his senior role in a system of governance that sought to undo the Enlightenment project. For him, the categorical imperative was the opposite of Kant's. The idea was to avoid putting oneself in another's shoes. Perhaps Eichmann was ordinary and representative but he was representative in a particular way. He was not one of Christopher Browning's Ordinary $M e n^{100}$ or, indeed, one of Daniel Goldhagen's Willing Executioners, ${ }^{101}$ Eichmann was exceptionally powerful. This Eichmann is alleged to have drafted the letter sent from Goring to Heydrich on 31 July 1941 authorizing a 'final solution' to the Jewish question. ${ }^{102}$

Then, there is the Adolf Eichmann who perfectly captures the breakdown of a moral universe; neither better nor worse than a thousand other Nazi functionaries, he somehow belongs behind a glass booth and on trial. He is the bureaucrat in his transparent office, a petty official, a former vacuum cleaner salesman who comes to be implicated in mass criminality; the accidental genocidaire. This is the 'banal Eichmann' that Hannah Arendt made notorious. He was certainly ordinary enough to escape indictment at Nuremberg though this is hardly conclusive. Fritzsche and Sauckel were unexceptional individuals, too. ${ }^{103}$ For Hannah Arendt, Eichmann was the petty bureaucrat, the clown who managed to work his way up the organisational ladder in the normal way; 'a German civil servant, absorbed in his work and getting no glory for it' (as Gerald Reitlinger put it). ${ }^{104}$ This Eichmann is ubiquitous. This is the Eichmann

\footnotetext{
${ }^{98}$ Hilberg (n. 88) 150.

99 I. Kant, Critique of Pure Reason (1781) (Cambridge University Press, Cambridge, 1999).

100 C. Browning, Ordinary Men: Reserve Police Battalion 101 and the Final Solution in Poland (Harper Collins, New York 1992).

101 D. Goldhagen, Hitler's Willing Executioners: Ordinary Germans and the Holocaust (Alfred A. Knopf, New york 1996).

102 Hilberg (n. 88) 78.

103 A. Neave, Nuremberg (Houghton and Stoughton, London 1978), p. 137.

${ }^{104}$ Lacquer (n. 97).
} 
who became Eichmann because of his trial. Prior to the trial, there would have been very little to write about this 'obscure lieutenant-colonel'. ${ }^{105}$ Since the trial, Eichmann has generated several biographies (the most recent of which is David Cesarani's Eichmann: His Life and Crimes $\left.{ }^{106}\right)$ and numerous essays and articles.

Before his trial, Eichmann was interviewed on several occasions. One of his interlocutors, an examining psychiatrist, was quizzed by the press about his views on the accused. Was he normal, they asked? He replied: 'More normal, at any rate, than I am having examined him.' ${ }^{107}$ When we look closely at the picture of Eichmann in his bullet-proof booth, we see a third Eichmann, represented in this case not by Eichmann himself but by the stenographer sitting in front of Eichmann: he is the very image of the original, a bespectacled doppelganger. This Eichmann is, of course, the Eichmann of our nightmares. Not inhuman, he is supremely human. He is the representative homo sapiens - no different, in some respects, from the man sitting in front of him. He is Tojo tending his garden ${ }^{108}$ or Hitler playing with his nieces. He is the man George Steiner describes who 'can read Goethe or Rilke in the evening... he can play Bach and Schubert and go to his day's work at Auschwitz in the morning'. ${ }^{109}$ Only circumstances change; man remains the same.

In 1961, Adolf Eichmann, in a Jerusalem prison, awaiting his trial for crimes against the Jewish people and crimes against humanity, would not have been aware of an experiment being conducted in the United States into a behavioural phenomenon with which he came to be associated. In that year, The New Haven Register carried an advertisement asking for volunteers to participate in a memory experiment. These were to be paid $\$ 4$ an hour to take part in a series of tests involving the application of electric shocks to a number of subjects. The volunteers were positioned in front of a fake shock machine that appeared to administer electric currents to the subjects (who, themselves, were insiders; part of the experimentation team). The electric shocks, increased in 15 volt segments reaching a maximum level of 415 volts, and were applied, in rising sequence, to 'wrong' answers given by the subject. The volunteers could hear, but not see, the subjects. The levers used to apply the shocks were marked from slight shock through severe shock to potentially

105 Lacquer (n. 97) 7. 106 D. Cesarani, Eichmann: His Life and Crimes (London 2004).

107 A. Granta, A Literature for Politics, Bill Buford (ed.) (Granta Books, London 1983), p. 25.

108 T. Maga, Judgment at Tokyo: The Japanese War Crimes Trials (Kentucky University Press, Lexington, KY 2002), p. 49.

109 G. Steiner, The Death of Tragedy (Faber, London 1961), p. 699. 
fatal shock. Severe shock began at 315 volts with death or severe injury reached at the maximum of 450 volts. As the shocks reached the 300 mark, the subject would often begin crying out in pain and desperation. 65 per cent of volunteers applied the full 450 volts, often in distress themselves and often in response to insistent assertions from the experiment leaders that the experiment continue. Stanley Milgram claimed to have conducted the experiments because he was curious about whether there were sufficient numbers of people in the United States who might have been capable of running a Nazi-style Lager in the United States. After the experiments, he concluded, wryly, that there were enough people in New Haven, Connecticut to operate the camps. ${ }^{110}$ The third Eichmann, then, is the most disturbing; he is unexceptional, an ordinary man receiving (and obeying) extraordinary orders.

In the end, there is an inescapable tendency to see mass criminality as an uniquely individualized expression of criminal psychopathology ('Hitler's evil mind') or a matter of socio-political joint responsibility (the failures of Versailles and the League), historical inevitability (the trajectory of modernity) or national temperament ('the German people'). The constitution of international criminal law has reflected these apparent tendencies at three different levels: in the institutional oscillations between state crime and individual responsibility, in the doctrinal ambiguities of a juridical order concerned with personal agency and collective conspiracies, and in the way the field is structured around the problem of the moral responsibility of groups and persons.

110 T. Blass, The Man Who Shocked the World: The Life and Legacy of Stanley Milgram (Basic Books, New York, NY 2004). 


\section{University Library}

\section{- M M N E R VA A gateway to Melbourne's research publications}

Minerva Access is the Institutional Repository of The University of Melbourne

Author/s:

SIMPSON, G

Title:

Men and abstract entities: Individual responsibility and collective guilt in international criminal law

Date:

2009

\section{Citation:}

SIMPSON, G. (2009). Men and abstract entities: Individual responsibility and collective guilt in international criminal law. Nollkaemper, A (Ed.). van der Wilt, $H($ Ed.). System Criminality in International Law, (1), pp.69-100. Cambridge University Press.

Persistent Link:

http://hdl.handle.net/11343/30139 